\title{
HERBAL CONTRACEPTIVES: EVALUATION OF ANTIFERTILITY POTENTIAL OF HIBISCUS ROSA-SINENSIS (LINN.)
}

\author{
SHIKHA BAGHEL CHAUHAN*, TANVEER NAVED
}

Department of Pharmaceutics, Amity Institute of Pharmacy, Amity University, Noida - 201 301, Uttar Pradesh, India. Email: shikha.pharma@gmail.com

Received: 13 April 2018, Revised and Accepted: 11 May 2018

\begin{abstract}
This review explores, evaluates, and analyzes the contraceptive potential of Hibiscus rosa-sinensis L. There are large numbers of synthetic contraceptives available in the market. These synthetic contraceptives are associated with many side effects ranging from user discomfort to toxicity. India is a land of traditional herbal medicines. People are finding and exploring the advantages associated with herbal contraceptives because of their lower side effects. Herbal contraceptives have lower cost of development as compared to modern medicine. This review explores the recent advances in development that offers many benefits for shifting the paradigm for herbal contraceptives. From times immemorial, references have been made for the plants that possess antifertility properties. This review explores the need for the development of herbal contraceptives from the plant $H$. rosasinensis L. H. rosa-sinensis L is reported to have antiovulatory activity. However, the need of the hour is to assess and carry out toxicological studies and initiate development activity for formulation development.
\end{abstract}

Keywords: Contraceptive, Herbal, Hibiscus rosa-sinensis L, Antifertility.

(C) 2018 The Authors. Published by Innovare Academic Sciences Pvt Ltd. This is an open access article under the CC BY license (http://creativecommons. org/licenses/by/4. 0/) DOI: http://dx.doi.org/10.22159/ajpcr.2018.v11i11.20531

\section{INTRODUCTION}

India being developing nation is still not able to cope up with the demerits of high population growth. There are a large number of devices, mechanisms, and techniques adopted for antifertility treatment. However, still people are very apprehensive to use synthetic chemicals and procedure because of long term after effects and side effects. Moreover, the procedures adopted to treat antifertility are irreversible in nature. Contraception is one of the proximate determinants of fertility and the most important predictor of fertility transition $[1,2]$. Family planning as a strategy for population stabilization received attention only after 1971 population census [3]. After the launch of the National Rural Health Mission (NRHM) in 2005, the official family planning program has been subsumed in the Reproductive and Child Health (RCH) component of the mission [4].

However, universal adoption of small family norm still remains a distant dream in India. During 2007-2008, only about 54\% of the currently married women aged 15-49 years or their husbands were using a contraceptive method to regulate their fertility [5] and the contraceptive prevalence rate appears to have stagnated after 2004 [6]. Reproductive health is intricately linked to issues of women's and children's health, the spread of sexually transmitted diseases, poverty, education, gender equality, and human rights [7]. Improving access to reproductive health is thus central to the process of development, as reflected in sustainable development goal [8].

Investment on family planning has multiple returns: Demographic, health, social, and economic benefits at individual, familial, and societal levels. Improved access and use of family planning improves child survival, reduces unwanted pregnancies and abortion, and improves health of mother and children [9]. Despite strong benefit of contraception, the pattern and use of contraception vary largely across countries. In developing countries, though the use of any contraceptive method has increased from $44 \%$ in 1980 to $61 \%$ in 2009 , the unmet need of contraception remains high, the method mix of contraception remains skewed, the quality of care of family planning services remained poor, and contraceptive discontinuation remained high [10-12]. To large extents, the unintended pregnancies are attributable to contraceptive discontinuation due to method failure and abandonment of contraception while being in the need [13]. In countries passing through demographic transition, a further decline in fertility depends on the consistent, correct, and effective use of contraception $[14,15]$. The contraceptive discontinuation varies greatly by the level of overall contraceptive use and by type of methods. The contraceptive discontinuation was lowest among intrauterine device (IUD), and implant users followed by injectable, condoms, and oral contraceptive users concluded that the method choice is endogenous to discontinuation [16-19]. The reasons associated with contraceptive discontinuation can be broadly categorized into four groups: Methodrelated reasons, contraceptive failure, reduced need, and non-methodrelated reasons. Among method-related reasons, health concerns and side effects were frequently cited by pill and IUD users, whereas accidental pregnancy was frequently cited among traditional method users $[20,21]$. The differentials in failure rates were largely due to differences in service delivery, user characteristics, and defining the failure rates [22]. In the United States, the failure rates for implants and IUDs were lowest, and it was highest for the traditional methods and spermicides [23]. Lack of adequate counseling and partner disapproved the use of method were more likely to discontinue a method [24].

India's demographic transition is of global significance due to its size (accounting $17 \%$ of global population) and large variation in demographic and health parameters within the country. Furthermore, the country has launched the largest flagship program, the NRHM, in 2005 , to improve the utilization of RCH services in the country and achieve the demographic targets, and fertility trends are diverging across states and districts of India [25].

However, the use of modern spacing method has not increased in India. This is further confirmed by reduction in the use of modern contraceptive method in 10 of the 15 states for which the key indicators from the National Family Health Survey- 3 have been recently released [26].

In a recent study on contraceptive use in India, 13 distinct groups that need programmatic attention to improve the family planning services and less focused on the post-adoption contraceptive behavior [27-32]. 
Shortly after the introduction of oral contraceptives, reports of adverse side effects associated with their use began to appear. Many of the side effects were found to be dose-dependent, and this led to the development of current low-dose preparations. Untoward effects of early hormonal

contraceptives fell into several major categories: Adverse cardiovascular effects, including hypertension, myocardial infarction, hemorrhagic or ischemic stroke, and venous thrombosis and

embolism; breast, hepatocellular, and cervical cancers; and a number of endocrine and metabolic effects [33].

There are various adverse effects associated with contraceptive pills and injectables including increased cholesterol levels, weight gain, headache, hypermenorrhea, depression, fatigue, and intermenorrheal bleeding. Since these are hormones, they also disbalance the metabolism of lipids, proteins, carbohydrates, enzymes, and vitamins [34]. The World Health Organization (WHO) suggested that effective, locally available plants be used as substitutes for drugs [35]

Although there are a large number of plants reported to have antifertility potential, even then, very few plants are explored for their long-term effects and therapeutically evaluated for toxicity analysis. The main problem lies in evaluating the active constituents in herbal extracts, batch-to-batch variations, and understanding their mode of action [36].

More than 35,000 plant species are being used in various human cultures around the world for medicinal purposes. Nearly $80 \%$ of the world populations rely on traditional medicines for primary health care, most of which involve the use of plant extracts $[37,38]$

From the advancement of reproductive biomedicine, several hormonal contraceptive pills have been developed but no one is free from different side effects for this purpose, the WHO has constituted a population control program, which includes studies having traditional medical practices. At present, global attempt has been taken to search out the effect of herbal product for contraceptive purposes [39].

Hence, there is a need for searching suitable product from indigenous medicinal plants that could be effectively used in the place of pills. All combination oral contraceptives contain both an estrogenic compound and a progestin. Over the years, the amounts and types of these components have changed in attempts to lower side effects and improve efficacy [40].

Herbal contraceptives are a category of herbs that have an antifertility effect. There are many different ways in which herbs can impair fertility. Some herbs may affect the ovary, while others act on the uterus, affect normal hormone production, or block certain hormones. For several of these, we do not really understand their action or how they got their reputation. Some herbs have the ability to interfere with implantation; these herbs can be taken on as needed basis and are used as an emergency contraceptive. There are also some herbs that have been found to interfere with normal sperm production or mobility. Each herb is used in its own way, so it is important to have some idea of how they are used or could be used [41].

Some herbal contraceptives have a cumulative effect in the body; they need to be taken regularly to maintain the contraceptive effect. Often needing a period of time to establish effectiveness, so a barrier method should be employed [42].

There is sufficient evidence in humans that combined oral estrogenprogesterone contraceptives are carcinogenic in nature. This assumption has made by increased risk for cancer of breast, cervical, and liver. However, experiments in animals have provided inadequate evidence for the carcinogenicity of progesterone, LNG, norgestrel, or progestinderived contraceptive pills. These contraceptives act as LH receptor
(LHR) and progesterone hormone receptor (PGR) inhibitors and thus in long-term usage interferes with the ovulation cycle which results in premature ovulation or delayed ovulation. However, herbal compounds have been found to work as partial inhibitors of LHR and PGR, and at the moment, they are being removed from the system, and the ovulation cycle is retained. Collectively, there is a need to work for herbal analogs of these contraceptives which can be effective as well as safe [43].

This review explores the antifertility potential of the plant Hibiscus rosasinensis $\mathrm{L}$. The best advantage of having herbal resources is that their action is reversible and they do not possess side effects to the body which leads to better patient compliance. The present article focuses on the contraceptive potential of $H$. rosa-sinensis, for enhancing the research potential in the development and evaluation of a herbal contraceptive.

\section{DESCRIPTION}

H. rosa-sinensis (Family Malvaceae) is an ornamental plant. It grows as an evergreen herbaceous plant. It bears large flowers on the bushy hedges. These enormous flowers are usually red in color and are not usually fragrant. Different cultivators and hybrids have been produced and developed with flowers ranging in colors and other features. The flowers have been reported to possess antiimplantation and antispermatogenic activities. The flowers have been reported to possess antiimplantation and antispermatogenic activities. The pharmacological effects of different parts of the plant HIBISCUS ROSA-SINENSIS (LINN.) as reported in the literature is mentioned in Table 1.

In Ayurveda, Hibiscus esculentus L. fruits are considered tonic, astringent, and aphrodisiac. In Unani medicine, the fruits are considered emollient and useful for treating urinary disorders [44].

The leaves and roots of Hibiscus manihot $\mathrm{L}$. are used as a poultice for boils, sprains, and sores, and the flowers are used to treat chronic bronchitis and toothache. The mucilage of the bark is considered to be an emmenagogue [45].

The seeds of Hibiscus abelmoschus L. are valued for their diuretic, demulcent, and stomachic properties and are considered stimulant, antiseptic, cooling, tonic, carminative, and aphrodisiac. The bark, flowers, and fruits of Hibiscus bauiferus. J.G. Froster are used externally for the treatment of skin diseases such as eczema, scabies, psoriasis, and ringworm. In Ayurvedic medicine, the bark is the official source of the drug "parisha," a reputed remedy for skin diseases.

According to the literature, many Hibiscus species have been investigated and found to contain many classes of secondary metabolites, including flavonoids, anthocyanins, terpenoids, steroids, polysaccharides, alkaloids, amino acids, lipids, sesquiterpene, quinones, and naphthalene groups. Some of these compounds have been shown to have antibacterial, anti-inflammatory, antihypertensive, antifertility, hypoglycemic, antifungal, and antioxidative activities [46-52].

Common name: Gudhal

Family: Malvaceae.

Chemical constituents [77]: Steroids, tannins, saponins, and flavonoids [53]

Activities [77]: Antispermatogenic and antiandrogenic activity [54 56,77].

Extract used [77]: 50\% ethanolic extract and benzene and benzene/ ether extract of flowers were showed antifertility activity [53-55].

Animal models [77]: Rats [55], non-scrotal bat [54], and mice [56] used for assessing antifertility activity of $H$. rosa-sinensis. 
Table 1: Pharmacological effects reported from different parts of the plant HIBISCUSROSA-SINENSIS (LINN.) (25)

\begin{tabular}{lll}
\hline Pharmacological effects & Extract & Part used \\
\hline Abortifacient effect & Ethanol (95\%), water, and petroleum ether extracts & Leaves, flowers, roots \\
Acid phosphatase stimulation & $(50 \%)$ ethanolic and benzene extracts & Flowers \\
Alkaline phosphate inhibition & Benzene and ethanol/water (1:1) extracts & Flower \\
Analgesic activity & Ethanol extract (70\%) $/ \mathrm{kg}$ \\
Androgenic effect & Benzene and ethanol (95\%) extracts & Dried leaves \\
Anticonvulsive effect & Ethanol extract & Dried flowers \\
Antifertility effect & Ethanol (95\%) extract & flower \\
Antifungal activity & Ethanol/water $(50 \%)$ extract & Dried flowers $/ \mathrm{kg}$ \\
Antigonadotropin effect & Benzene extract & Dried leaves \\
Antiimplantation effect & Benzene extract & Dried flower \\
Antipyretic activity & Ethanol (70\%) extract & - \\
Antispasmodic activity & Ethanol/water $(1: 1)$ extract $/ \mathrm{kg}$ \\
Antispermatogenic effect & Benzene extract dried & Dried flowers \\
CNS depressant activity & Ethanol/water $(1: 1)$ extract & Dried leaves \\
Anti-inflammatory activity & Ethanol (70\%) extract & - \\
Antiviral activity & (80\%) ethanol extract & $250 \mathrm{mg} / \mathrm{kg}$ \\
Antiestrogenic effect & Benzene extract & $250 \mathrm{mg} / \mathrm{kg}$ \\
\hline
\end{tabular}

\section{CHEMICAL CONSTITUENTS [78]}

H. rosa-sinensis plant extracts contain alkaloids, glycosides, fatty materials, reducing sugars, resin, sterols, and the lack of tannins and saponins [78]. Isolation of $\beta$-sitosterol, taraxeryl acetate, and four uncharacterized compounds which included an alkaloid and three sterols has been reported in the leaves [78]. The leaves of H. rosasinensis were also investigated for their fatty alcohol, fatty acids, and hydrocarbon content [58]. Two cyclic acids, namely, malvalic and sterculic are also identified $[57,78]$.

Flowers contain vitamins, flavonoids, ascorbic acid, niacin, riboflavin, thiamine, and cyaniding diglucoside [78]. Quercetin-3-diglucoside, cyanidin-3-sophoroside-5-glycosides, 3,7-diglucoside, cyanidin-3,5diglucoside have been isolated from deep yellow flowers [58].

\section{PREPARATION OF BENZENE EXTRACT}

\section{Preparation of extract}

All the flowers were shade direct at room temperature and finely powdered with the help of mixer grinder. About $150 \mathrm{~g}$ of the powder was extracted with benzene. The extract was concentrated to a residue. The crude extract was used for further testing for its phytochemical compounds $[59,79]$.

The benzene extract of $H$. rosa-sinensis flowers was administered intraperitoneally at the dose levels of 125 and $250 \mathrm{mg} / \mathrm{kg}$ body weight to adult mice and resulted in an irregular estrous cycle with prolonged estrus and metestrus [79]. An increase in the atretic follicles and the absence of corpora lutea indicate the antiovulatory effect of the extract [79]. The extract also showed estrogenic activity in immature mice by early opening of the vagina, premature cornification of the vaginal epithelium, and an increase in uterine weight [79]. Therefore, the antiovulatory effect may be due to an imbalance in the hormonal environment, as there may be an increase in the endogenous secretion of estrogen by atretic follicles and also to the estrogenicity of the flower extract $[60,79,80]$.

\section{Japakusuma (H. rosa-sinensis)}

Alcoholic extract of flower exhibited significant 50-60\% inhibition of pregnancy at $200 \mathrm{mg} / \mathrm{kg}$ dose [80]. Benzene extract (total) produced $100 \%$ antifertility effect in $250 \mathrm{mg} / \mathrm{kg}[61,80]$. Alcoholic extract of leaves and branches caused $30 \%$ antifertility activity only [80]. Flowers of the plant caused abolition of regular estrus cycle in rats [80]. The ethanol extract of flower was devoid of antifertility effect, i.e. antispermatogenic, antiovulatory, antiimplantation, and abortifacient activity at $400 \mathrm{mg} / \mathrm{kg}$, p.o. day. Benzene extract of flower of H. rosa-sinensisin $100 \mathrm{mg} / \mathrm{kg}$ exhibited post-coital antifertility effect in $80 \%$ of treated female rats $[62,80]$.
The drug is having antifertility and antispermatogenic and antiestrogenic activities [63-67,80]. Benzene extract of flower in $250 \mathrm{mg} / \mathrm{kg}$ from day 1 to day 10 of pregnancy in rats was found most effective to prevent pregnancy.

\section{THERAPEUTIC EVALUATION}

\section{Reproductive potential of $H$. rosa-sinensis}

The effect of $H$. rosa-sinensis linn. on the estrous cycle and reproductive organs was studied in female albino rats [64]. Depending on the dose and duration of treatment, the benzene extract of the flowers disrupted the estrous cycle [64]. Treatment for 30 days resulted in a significant $(\mathrm{p}<0.05)$ reduction in the weight of the ovaries, uterus, and pituitary gland [64]. Ovarian follicular atresia and uterine atrophy were observed. Treatment resulted in degranulated gonadotrophs in the pituitary, with the extent of damage being dose-dependent [64]. Ancient literature mentions the use of a number of plants/preparations for fertility regulation [76]. Some local contraceptive agents have also been described in Ayurvedic and Unani texts [76]. Documented experiments or clinical data are, however, lacking [76]. Therefore, the present study was undertaken to explore the antifertility and estrogenic activity of ethanolic extract of the roots of $H$. rosa-sinensis linn. [76]. A strong antiimplantation (inhibition 100\%) and uterotropic activity were observed at the dose level of $400 \mathrm{mg} / \mathrm{kg}$ body weight [76]. Histological studies were carried out to confirm this effect $[65,78]$.

\section{Antispermatogenic and androgenic activities}

The oral administration of benzene extract of $H$. rosa-sinensis flowers (250 mg/kg daily for 30,45 , and 60 days) was found to affect spermatogenesis as well as the endocrine function of the testis as studied by weight changes, histology, and biochemical estimations [78]. The effect of extract on spermatogenesis ranged from mild damage of germinal epithelium to nearly total sloughing depending on the duration of treatment. Similarly, reduction in weight of the testes, accessory sex organs, and pituitary was observed [78]. The alkaline phosphatase in ventral prostate, citric acid content in seminal vesicles, and dorsolateral prostate fructose concentration were also reduced [78]. The accessory reproductive organs showed loss of secretory activity while pituitary showed degranulation of gonadotrophs [78]. However, these effects were reversible after discontinuation of treatment. It seems probable that the effects of the drug are mediated through pituitary $[66,76]$.

\section{Antiovulatory and antiestrogenic activities}

Japa flowers (H. rosa-sinensis) is to be given orally in the form of paste along with kanji (rice gruel) and 400-year-old guda (jaggery) in the dose one pala ( $48 \mathrm{~g}$ ) for 3 consecutive days during menstruation [67]. Antiovulatory and antiestrogenic activity has also been discussed and described in Bhavaprakasa of bhavmisra Vidyotini hindi commentary by Brahmasanker misra. 
In mouse, oral administration of the benzene extract of $H$. rosasinensis flowers at a dose level of $1 \mathrm{~g} / \mathrm{kg}$ body weight/day from day 5 to 8 of gestation led to termination of pregnancy in about $92 \%$ of the animals [67]. The effect was associated with a significant fall in peripheral level of progesterone and increase in uterine acid phosphatase activity, as measured on day 10 [67]. The ovary exhibited signs of luteolysis, and the corpus luteal delta 5-3 beta-hydroxysteroid dehydrogenase activity decreased markedly [67]. The interceptive effect of the extract was prevented completely by exogenous progesterone (1 mg/mouse/day) or chorionic gonadotropin (1 I.U./mouse/day) and partially (62.5\%) by exogenous prolactin (500 $\mu \mathrm{g} /$ mouse/day) [22]. In unilaterally pregnant mouse having trauma-induced deciduomata in the sterile horn, the extract caused resorption of the fetuses, and regression of the deciduomata accompanied by reduction in weight of the ovaries [67]. Luteolysis may be due to interference with the luteotropic influence, and a consequent fall in plasma level of progesterone has been suggested as the plausible cause of termination of pregnancy [67].

\section{Antiimplantation activity}

$H$. rosa-sinensis flowers have been shown to possess antifertility and abortifacient activity [68]. In this report, anti-implantation activity of water extract of leaves of $H$. rosa-sinensis was investigated [68]. Pregnant female mice were dosed with extract $(100 \mathrm{mg} / \mathrm{kg}$ body weight) from days 1 to 6 of pregnancy [68]. No implantation sites were observed in treated animals when they were surgically opened on day 15 of pregnancy. Biochemical and biophysical alterations were observed in the endometrium in treated animals, especially on day 5 , at 4:40 a.m., the day of implantation [68]. A sharp increase in superoxide anion radical and a sharp fall in superoxide dismutase (SOD) activity, as seen in the endometrium from control animals, were altered in treated animals [68]. The extract also exhibited antiestrogenic activity, as judged by increase in uterine weight [68]. The physiological alterations induced by water extract of $H$. rosa-sinensis are discussed [68].

Many plants are known to possess antifertility activity [68]. However, limited attempts have been made to scientifically evaluate these claims [68].

\section{Therapeutic evaluation}

There are also important new findings concerning the antiherpes simplex virus activity of Mangifera indica, the anti-Parkinson's activity of Mucuna pruriens, the antiviral activity in Phyllanthus niruri and Jatropha curcas, the hyperthyroid regulation properties of Moringa pterygosperma, and the antioxidant activity of Mangifera indica, Punica granatum, Psidium guajava, and Allium sativum. Allium sativum is highlighted for its treatment of unstable angina pectoris, sickle red blood cell dehydration inhibition, senescence ameliorative, chemoprotective, cardiovascular, antineoplastic, anticarcinogenic, and antiatherogenic effects.[70] In a clinical trial, treatment of 21 women at reproductive age group with ethanolic extract of H. rosa-sinensis flowers at $750 \mathrm{mg} /$ $\mathrm{kg}$ body weight/ day in 3 doses, from 7 th to $22 \mathrm{nd}$ day of menstrual cycle [72], 14 women did not have pregnancy for 4 years, whereas 7 women dropped out of the trial $[71,72]$. The trials were also conducted with Vidangadi yoga (a herbal preparation containing Embelia ribes seeds, H. rosa-sinensis flowers, and Ferula foetida oleo-gum resin) for antifertility activity, and the drug was found to be quite effective without any harmful effects [71].

Evaluation of the herbal medicinal plants has been in progress for several decades to identify effective and safe substances for fertility regulation. Several medicinal plant extract were investigated for their antifertility activity both in male and female animal models. [73]

Hibiscus rosa sinensis possess many properties and this plant may procured at large scale for providing herbal alternative to many diseases. The phytochemical screening on qualitative analysis shows that the plant is rich in alkaloids, terpenoids, flavonoids, glycosides, reducing sugar, Fatty materials, saponins, gums and mucilage. [74] he benzene extract of Hibiscus rosa sinensis flowers was administered intraperitoneally at the dose levels of 125 and $250 \mathrm{mg} / \mathrm{kg}$ body weight to adult mice and resulted in an irregular estrous cycle with prolonged estrus and metestrus. An increase in the atretic follicles and the absence of corpora lutea indicate the antiovulatory effect of the extract. The extract also showed estrogenic activity in immature mice by early opening of the vagina, premature cornification of the vaginal epithelium and an increase in uterine weight. Therefore the antiovulatory effect may be due to an imbalance in the hormonal environment, as there may be an increase in the endogenous secretion of estrogen by atretic follicles, and also to the estrogenicity of the flower extract.[75].

For antifertility activity, the percentage fertility on female mice for control, $500 \mathrm{mg} / \mathrm{kg}$ and $1000 \mathrm{mg} / \mathrm{kg}$ were $100 \%, 20 \%$ and $33.33 \%$, respectively. Histopathology study showed abnormality effects on ovaries for higher dose concentration and size decrease effects on fallopian tubes which are responsible for antiimplantation. These results indicate that Sida cordifolia produced mainly abortifacient activity and antiimplantation activity [79].

In a study carried out for the evaluation of antifertility potential of Portulaca oleracea L. in female albino rats, it was found that the weights of the ovary and uterus of both low and high doses increased when compared to control group. The increase in the wet weight of the ovary in the extract-treated animals compared to the control animals may indicate inhibition of ovulation through suppression of follicularstimulating hormone [80].

\section{TOXICITY ASSESSMENT}

Treatment with ethanol/water (1:1) extract of the aerial parts, administered intraperitoneally to both sexes of mice, produced LD50 $1.0 \mathrm{~g} / \mathrm{kg}$ [72].

Why herbal contraceptives lagging behind the modern pill? This is an obvious question that comes in our mind. Several factors are responsible for this. One major factor is that it is impossible for us to say how effective they are as the information are remain scarce and fragmented and transmitted orally among ethnic people. The model animal-based scientific description of very little number of plants is available till now. Furthermore, very little is known about long-term side effects associated with these herbal preparations. Although many plants have birth controlling bioactive compound, standardization of these compounds as birth controlling drugs remains a challenging task. The concentration and potential of active constituents of a plant are variable according to the variation in season and biogeographical regions. Hence, the reliability of herbal contraceptive remains uncertain, and people do not show much interest in this "eco-friendly" birth control option [81].

\section{CONCLUSION}

This review summarizes the traditional values and antifertility activity of $H$. rosa-sinensis. Through the vast literature supports and researches, it is very clear that the plant possessive antiimplantation property. Since there is a huge scope of development of herbal contraceptives, these medicinal plants should be formulated and developed into herbal contraceptives which are easy to use, causes least discomfort and have no side effects. It is suggested to explore the detailed mechanism of action and effects on reproductive organs and the changes in hormone levels. It possesses a huge potential for the development of natural contraceptive which can be a great boon to the society.

The plant kingdom holds many species of plants containing substances of medicinal value that have yet to be discovered. A large number of plants are constantly being screened for their possible pharmacological value. The Hibiscus genus may prove to be a richer source of compounds with possible pharmacological value, but more investigations are necessary in this direction. 
The reported biological studies of Hibiscus were carried out mostly on various extracts, but more attention is required to screen the phytoconstituents responsible for these activities.

\section{ACKNOWLEDGMENT}

Amity University, Noida, is gratefully acknowledged.

\section{AUTHOR'S CONTRIBUTIONS}

Ms. Shikha Baghel Chauhan has collected the data and compiled and drafted the article. Dr. Tanveer Naved has reviewed the article.

\section{CONFLICTS OF INTEREST}

The author(s) declared no potential conflicts of interest with respect to the research, authorship, and/or publication of this article.

\section{REFERENCES}

1. Davis K, Blake J. Social structure and fertility: An analytical framework. Econ Cult Change 1956;4:211-35.

2. Bongaarts J. A framework for analysing proximate determinants of fertility. Popul Dev Rev 1978;4:105-31.

3. Chaurasia AR, Gulati SC. India: The State of Population 2007. New Delhi, India: Government of India, National Population Commission and Oxford University Press; 2008.

4. Chaurasia AR, Singh R. Forty Years of Planned Family Planning Efforts in India. In: Proceedings of the 2013 IUSSP International Population Conference, Bussan, Republic of Korea, 2013. Bussan, Republic of Korea: The 2013 IUSSP International Population Conference; 2013.

5. International Institute for Population Sciences, District Level Household and Facility Survey (DLHS-3), 2007-08, IIPS, Mumbai, India; 2010.

6. United Nations. Update for the MDG Database: Contraceptive Prevalence. New York, USA: Department of Economic and Social Affairs, Population Division; 2012.

7. United Nations Population Division (UNPD), Department of Economic and Social Aff airs. Guidelines on Reproductive Health; 1995.

8. United Nations, General Assembly. Transforming our World: The 2030 Agenda for Sustainable Development, No. A/RES/70/1. Oct 21, 2015.

9. Kavanaugh ML, Anderson RM. Contraception and Beyond: The Health Benefits of Services Provided at Family Planning Centers. New York: Guttmacher Institute;

10. Bertrand G. Simple points, topological numbers and geodesic neighborhoods in cubic grids. Pattern Recognit Lett ;15:1003-11.

11. Steele F, Diamond I. Contraceptive switching in Bangladesh. Stud Fam Plann :30:315-28.

12. Sullivan TM, Bertrand JT, Rice J, Shelton JD. Skewed contraceptive method mix: Why it happens, why it matters. J Biosoc Sci ;38:501-21.

13. Cleland J, Ali MM. Reproductive consequences of contraceptive failure in 19 developing countries. Obstetr Gynecol ;104:314-20.

14. Blanc AK, Curtis SL, Croft TN. Monitoring contraceptive continuation: Links to fertility outcomes and quality of care. Stud Fam Plann ;33:127-40.

15. Vaughan B, Trussell J, Kost K, Singh S, Jones R. Discontinuation and resumption of contraceptive use: Results from the 2002 national survey of family growth. Contraception ;28:271-83.

16. Ali M, Cleland J. Contraceptive discontinuation in six developing countries: A cause-specific analysis. Int Fam Plann Perspect ;21:92-7.

17. Blanc AK, Curtis SL, Croft TN. Monitoring contraceptive continuation: Links to fertility outcomes and quality of care. Stud Fam Plann 2002;33:127-40.

18. Bradley SE, Schwandt H, Khan S. Levels, Trends, and Reasons for Contraceptive Discontinuation (DHS Analytical Studies No. 20). Calverton, MD: Macro International;

19. SteeleF,Curtis S.Appropriate methods for analyzing the effect of method choice on contraceptive discontinuation. Demography ;40:1-22.

20. Mitra SN, Al-Sabir A. Contraceptive use Dynamics in Bangladesh (DHS Working Paper No. 21). Calverton, MD: Macro International;

21. Singh KK., Roy TK, Singh BP. Contraceptive discontinuation and switching patterns in Bangladesh. Genus ;66:63-88.

22. Jejeebhoy SJ. Women's status and fertility: Successive crosssectional evidence from Tamil Nadu, India, 1970-80. Stud Fam Plann ;22:217 30

23. Trussell J. Contraceptive failure in the United States. Contraception ;83:397-404.

24. Cotten N, Stanback J, Maidouka H, Taylor-Thomas JT, Turk T. Early discontinuation of contraceptive use in Niger and the Gambia. Int Fam Plann Perspect ; 18:145-9.

25. Mohanty SK, Fink G, Chauhan RK, Canning D. Distal determinants of fertility decline: Evidence from 640 Indian districts. Demogr Res ;34:373-406.

26. International Institute for Population Sciences. National Family and Health Survey, 2015-15 (State Fact Sheet). Ministry of Health and Family Welfare, Government of India; Available from: http://www. rchiips.org/nfhs/factsheet NFHS-4.shtm.

27. Chaurasia AR. Contraceptive use in India: A data mining approach. Int J Popul Res :Article ID: 821436, 11 Pages.

28. Bhat PM, Zavier AF. Role of religion in fertility decline: The case of Indian Muslims. Econ Polit Wkly ;40:385-402.

29. Guilmoto CZ, Rajan SI. Spatial patterns of fertility transition in Indian districts. Popul Dev Rev ;27:713-38.

30. Mohanty SK, Ram F. Spatial pattern of poverty reduction and fertility transition in India. Popul Rev ;50:62-78.

31. Ram U, Dwivedi LK, Goswami B. Understanding contraception use among Muslims of India, Pakistan and Bangladesh. J Popul Soc Stud ;15:101-30.

32. Zhang F, Tsui AO, Suchindran CM. The Determinants of Contraceptive Discontinuation in Northern India: A Multilevel Analysis of Calendar Data. Chapel Hill: MEASURE Evaluation, Carolina Population Center, University of North Carolina at Chapel Hill;

33. Mohamed GA, Ibrahim SR, Al Haidari RA. A review on natural contraceptive agents. Am J PharmTech Res 2014;4:124-58.

34. Unny R, Chauhan AK, Joshi YC, Dobhal MP, Gupta RS. A review on potentiality of medicinal plants as the source of new contraceptive principles. Phytomedicine 2003;10:233-60.

35. Sathiyaraj K, Sivaraj A, Thirumalai T, Senthilkumar B. Ethnobotanical study of antifertility medicinal plants used by the local people in Kathiyavadi village, Vellore District, Tamil Nadu, India. Asian Pac J Trop Biomed 2012;2:S1285-8.

36. Priya G, Saravanan K, Renuka C. Medicinal plants with potential antifertility activity-A review of sixteen years of herbal medicine research (1994-2010). Int J PharmTech Res 2012;4:481-94.

37. Shah GM, Khan MA, Ahmad M, Zafar M, Khan AA. Observations on antifertility and abortifacient herbal drugs. Afr J Biotechnol 2009;8:1959-64.

38. Kaur R, Sharma A, Kumar R, Kharb R. Rising trends towards herbal contraceptives. J Natl Prod Plant Resour 2011;1:5-12.

39. Ahmad S, Jamal Y, Mannan A: Review of some medicinal plants with anti-fertility activities. Unani Res 2011;1:24-8.

40. Qureshi AA, Sanghai DB, Padgilwar SS. Herbal options for contraception: A review. Pharmacog Mag 2006;2:204-15.

41. Kaur R, Sharma A, Kumar R, Kharb R. Rising trends towards herbal contraceptives. J Natl Prod Plant Resour 2011;1:5-12.

42. Umadevi M, Kumar PS, Bhowmik D, Duraivel S. Medical plants with potential antifertility activity. J Med Plants Stud 2013;1:26-33.

43. Shukla A, Jamwal R, Bala K. Adverse effect of combined oral contraceptive pills. Asian J Pharm Clin Res 2017;10:17-21.

44. Parrota AJ. Healing Plants of Peninsular India. New York: CABI Publishing; 2001. p. 475-8.

45. Chopra RN, Nayar SL, Chopra IC. Glossary of Indian Medicinal Plants. New Delhi: CSIR; 1950. p. 133.

46. Kholkute SD. Effect of Hibiscus rosa-sinensis on spermatogenesis and accessory reproductive organs in rats. Planta Med 1977;31:127-35.

47. Parmar NS, Ghosh MN. Antiinflammatory activity of gossypin, a bioflavonoid isolated from Hibiscus viti-folius. Linn. Indian J Pharmacog 1978;10:277-29.

48. Gangrade H, Mishra SH, Kaushal R. Antimicrobial activity of oil and unsaponifiable matter of red roselle. Indian Drugs 1979;16:147-8. 
49. Jain R, Arora R, Jain SC. Chemical constituents and bioactivity studies of Hibiscus micranthus. Linn. Indian J Pharm Sci 1997;91-3.

50. Faraji MH, Tarkhani AH. The effect of sour tea (Hibiscus sabdariffa.) on essential hypertension. J Ethnopharmacol 1999;65:231-6.

51. Lin WL, Hsieh YJ, Chou FP, Wang CJ, Cheng MT, Tseng TH. Hibiscus. protocatechuic acid inhibits lipo-polysaccharide induce rat hepatic damage. Arch Toxicol 2003;77:42-7.

52. Sachdewa A, Khemani LD. Effect of Hibiscus rosa-sinensis. Linn, ethanol flower extract on blood glucose and lipid profile in streptozotocin induced diabetes in rats. J Ethnopharmacol 2003;89:61-6.

53. Jadhav VM, Thorat RM, Kadam VJ, Sathe NS. Hibiscus rosa-sinensis Linn-“Rudrapuspa”: A review. J Pharm Res 2009;2:1168-73.

54. Srivastava DN, Bhatt SK, Udupa KN. Gas chromatographic identification of fatty acids, fatty alcohols, and hydrocarbons of Hibiscus rosa-sinensis leaves. J Am Oil Chem Soc 1976;53:607-8.

55. Agarwal S, Prakash R. Phytochemical analysis of the benzene extract of Hibiscus rosa-sinensis. Ultra Chem 2013;9:178-9.

56. Murthy DR, Reddy CM, Patil SB. Effect of benzene extract of Hibiscus rosa-sinensis on the estrous cycle and ovarian activity in albino mice. Biol Pharm Bull 1997;20:756-8.

57. Kholkute SD, Udupa KN. Antifertility properties of Hibiscus rosasinensis. J Res Indian Med 1974; 9:105.

58. Batta SK, Santhakumari G. The antifertility effect of Ocimum sanctum and Hibiscus cosa sinensis. Indian J Med Res 1970;59:777-81.

59. Gupta ML, Gupta TK, Bhargava KP. A Study of antifertility effects of some indigeneous drugs. J Res Ind Med 1971;6:46-51.

60. Prakash AO. Effect of Hibiscus rosa-sinensis Linn. extracts on corpora lutea of cyclic guinea pigs. Sci Cult 1980;46:330-1.

61. Singh SP, Singh N, Kohli RP. Antifertility Studies of some indigenous plants. Indian J Pharmacol 1978;10:88.

62. Singh MS, Lal SB. Cytostatic and cytotoxic effects of flower extract of Hibiscus rosa-sinenses on spermatogenically and and rogenically active testes of a non-scrotal bat; Rhinopoma kinneari wroughton. Indian J Exp Bio 1980;18:1405

63. Tewari PV. Preliminary clinical trial on flowers of Hibiscus rosasinensis as an oral contraceptive agent. J Res Indian Med 1974;9:105.

64. Kholkute SD, Chatterjee S, Udupa KN. Effect of Hibiscus rosa-sinensis Linn. on oestrous cycle and reproductive organs in rats. Indian J Exp Biol 1976;14:703.

65. Vasudeva N, Sharma SK. Post-coital antifertility activity of Hibiscus rosa-sinensis Linn. roots. Evid Based Complementary Altern Med 2008;5:91-4.

66. Kholkute SD. Effect of Hibiscus rosa-sinensis on spermatogenesis and accessory reproductive organs in rats. Planta Med 1977;31:127-35.
67. Pakrashi A, Bhattacharya K, Kabir SN, Pal AK. Flowers of Hibiscus rosasinensis, a potential source of contragestative agent. III: Interceptive effect of benzene extract in mouse. Contraception 2005;71:227-30.

68. Nivsarkar M, Patel M, Padh H, Bapu C, Shrivastava N. Blastocyst implantation failure in mice due to "nonreceptive endometrium": Endometrial alterations by Hibiscus rosa-sinensis leaf extract. Contraception 2005;71:227-30.

69. Nivsarkar M, Patel M, Padh H, Bapu C, Shrivastava N. Blastocyst implantation failure in mice due to "nonreceptive endometrium": Endometrial alterations by Hibiscus rosa-sinensis leaf extract. Contraception 2005;71:227-30.

70. Ross IA. Constituents, Traditional and Modern Medicinal Uses. Vol. 1. New York: CBS Publishers; 2001. p. 257-60.

71. Sharma PC, Yelne MB, Dennis TJ, Joshi A, Billore KV. Database on Medicinal Plants used in Ayurveda. New Delhi: Central Council for Research in Ayurveda \& Siddha; 2000.

72. Bhakuni OS, Dhar ML, Dhar MM, Dhavan BN, Mehrotra BN. Screening of Indian plants for biological activity, Part II. Indian J Exp Biol 1969;7:250-62.

73. Devi P, Kumar P, Dhamija I. Antifertility activity of medicinal plants on male and female reproduction. Int J Pharm Sci Res 2015;6:988.

74. Pekamwar SS, Kalyankar TM, Jadhav AC. Hibiscus rosa-sinensis: A review on ornamental plant. World J Pharm Pharm Sci 2013;2:4719-27.

75. Murthy DR, Reddy CM, Patil SB. Effect of benzene extract of Hibiscus rosa-sinensis on the estrous cycle and ovarian activity in albino mice. Biol Pharm Bull 1997;20:756-8.

76. Jain CM, Bharathi K. Critical review of scientific validity of indigenous female contraceptive drugs described in Ayurvedic literature. Indian J Trad Knowl 2011;10:678-81.

77. Jana TK, Das S, Ray A, Mandal D, Jana SG, Bhattacharya J. Study of the effects of Hibiscus-rosa-sinensis flower extract on the spermatogenesis of male albino rats. J Physiol Pharmacol Adv 2013;3:167-71.

78. Kholkute SD. Effect of Hibiscus rosa-sinensis on spermatogenesis and accessory reproductive organs in rats. Planta Med 1977;31:127-35.

79. Pokale S, Kulkarni K. Evaluation of antifertility potential of aqueous extract of Sida cardifolia linn. Plant in swiss albino mice. Int J Pharm Pharm Sci 2012;4:128-31.

80. Nayaka HB, Londonkar RL, Umesh MK. Evaluation of Portulaca oleracea L. For anti-fertility effect in female albino rats. Int J Pharm Pharm Sci 2014;6:86-9.

81. Anand AK, Prasad V, Alam M. Herbal or modern methods of contraception! Choice is yours. Int J Reprod Contracept Obstet Gynecol 2015;4:947-53. 